\title{
THE UNITED NATIONS AND THE HUMAN RIGHTS ISSUE*
}

\section{Allard Lowenstein $\dagger$}

I am now the United States Ambassador to the United Nations for Special Political Affairs. Part of my function in that job is to involve the United States mission at the United Nations in the global concerns of the Carter Administration about repression and injustice. Andrew Young is the central figure in the world on these questions. It is extraordinary that the United States is represented by Young because the various facets of the struggle for human rights in this country are reflected in his life. He worked with the Rev. Martin Luther King, which means that he is a link to the central figure of our generation in the struggle for racial justice, but beyond that particular association he has the extraordinary capacity to be overwhelmingly human in a scene where that is unheard of. For the first time since Eleanor Roosevelt represented the United States at the United Nations, an American is the central figure of the nerve center of our effort to promote human rights-that is to reduce suffering-in the world. That is the central fact about Andrew Young representing us at the United Nations. It is profitable for us as a nation and for that effort to have him there. He is both symbol and leader, inspiring those who work to speed the realization of Martin Luther King's dream. Periodic disagreement about specific views or statements is a small price to pay for the great benefits that flow from having such a man as our chief representative at the United Nations.

It is easy to remember a time when whatever good motives we had, there was much that was troubling about how we were using our power in the world. We were using that power to wipe out villages 10,000 miles away where nobody knew who we were, where they could not have hurt us if they had wanted to. We were instrumental in keeping governments in power that stayed in power by oppressing their own people-a state of affairs somehow confused with protecting our own national security. If you measure these changes in atmosphere and direction fairly, the Carter Administration has done a lot in a short time, and countless human beings who were born into a life of difficulty and struggle are the better for it.

\footnotetext{
* Lecture at the Symposium, Protecting the Right to Dissent, Duke University School of Law, February 24-25, 1978, published posthumously.

$\dagger \mathrm{Mr}$. Lowenstein was a practicing attorney in New York City and former U.S. Ambassador to the United Nations for Special Political Affairs and United States Representative to the U.N. Commission on Human Rights and Trusteeship Council.
} 
It is a rare opportunity when the country with the greatest resources in the world, the greatest power, the greatest sense of what right is about, gives people the responsibility and power to try to do the things which we have always wanted to do and said that we cared about doing. It does not seem justifiable to me or even understandable that the communities most conscientious about these questions are least active and least concerned, are inclined to quibble and to argue.

I think we should be upset about the relationship with the Shah. I think we should be concerned about what we are doing about the Philippines. I think there is plenty of ground for public pressure on the U.S. government to do better things in many countries. The world has central questions that ought to be addressed. One of them, of course, is the right to dissent. I think one of them is the right of the planet to survive. One of [our] great paradoxes is that, for the first time since Cain killed Abel, we can now wipe out half the earth's population in five minutes; we must figure out a way to get past wars as an instrument to settle differences. That is a factor that $I$ do not think most people have accepted yet. Certainly most military people have not. There is an extraordinary notion that war is still the way to continue foreign policy when you cannot figure out what else to do.

The limits imposed by the reality of weaponry and technology must be gestated into the kind of policy decisions that people make. What can you do about eastern Europe? What can you do about China? Not the same thing you could do if you think of war as a tactic that makes sense. We must devise a way to achieve human rights peacefully.

I think the Carter Administration, beginning with the President's remarks when he took office, is trying to undo the long, difficult period that we experienced under preceding presidencies. The President has made guidelines available to people who care about decreasing suffering wherever they may live, whatever the cost to tradition may be, and whatever the source of suffering. We are clear about where we stand and what we want to do. The President dispatches people around the world to talk about human rights. This is unprecedented. We go to these countries, whether it is Andrew Young, Pat Darian, Mark Schneider or [myself] and there is no question about why we are there or what we care about. There is no question that what we are saying to people in those countries has to do with decreasing suffering. We are not concerned with more effective armaments to stop another country from advancing or treaties to guard borders. We are concerned with what we will do cooperatively to make life less difficult for everyone.

Governments are not and should not be all-powerful. There are limits on what governments can do. Since so much suffering comes from governments, governments ought to be the source of some of the effort to change that suffering. That is what we are trying to achieve. In many places the change is measurable in the climate of a country. It is measurable because governments 
have a different understanding now-the same governments that used to understand that if you want to make the United States happy (which governments do) you should be anticommunist, you should be repressive if you have dissent from the left, you should do things that are consistent with the wishes of the American government.

President Carter appointed me to be a representative at the Geneva human rights session. My instructions were, "to do what you think is right." I did not understand what a valuable piece of instruction that was or how unique it was. The first thing I did in Geneva was to talk, just talk; not recite the choreographs that were mailed out; not limit what I said to what had been approved by the committee.

If you talk, you run the risk of saying something wrong. You may be misinterpreted. If you make a mistake, you say so. It does not denigrate the value of your country. It simply means that you have enough sense to know that nobody is perfect, not even you. You proceed with the understanding that that is part of the process of dialogue. Everyone is accustomed to having everything read from prepared texts which are mimeographed and distributed; everybody knows exactly what is going to be said. If you talk without a prepared text, they listen.

The first thing I talked about in Geneva was what I considered the atrocious resolution on the Middle East concerning the Israelis being torturers, murderers and aggressors. I proposed a new text on human rights in the Middle East, showed it to the Arab countries and they did not want to talk about it. I moved that we delete the objectionable part of the resolution and proceed to the next part. The Syrian ambassador told me that Israel is an aggressor because of a General Assembly resolution that says that if you occupy a territory, you are an aggressor. It troubled me that, if that is the test, the United States, the United Kingdom, the Soviet Union, France and others who occupied any part of Germany, Italy or Japan after World War II are aggressors. It was not clear if that resolution meant that a country is an aggressor if they occupy territory before or after a peace treaty, in violation of that treaty. We lost the vote on my resolution. We did not expect to win it. What was fascinating about it was that, before we were through, an open discussion developed. The Egyptian ambassador, an estimable character, was involved.

In that session of the Human Rights Commission, we voted on human rights issues where you could not predict the outcome in advance. Countries did not vote predictably in blocks on questions where that had been the case in the past. If you vote in blocks, you do not discuss issues intelligently because it is polemicized. We talked about dissent in the Soviet Union; we insisted that we discuss the arrests of Orlov, Ginsberg and others who were monitoring the Helsinki Final Act. We had a new enthusiasm for voting from countries and delegates. 
The most extraordinary event in Geneva was not that we insisted on discussing the arrests of Orlov and Ginsberg, but that when the Russians made an effort to block that discussion, not a single developing country voted with them. I believe the reason that happened was that there was a sense in the Commission that something more than polemicized confrontation or tired repetitive rhetoric was involved. We were saying that we care universally about these questions and we want to talk about them. We want to talk about them wherever they may be a problem, including our own country.

At the Human Rights Commission I said that I represented the people that had given the world perhaps the most electrifying battle cry for human rights in all history: that all men are created equal, that they are endowed by their Creator with certain inalienable rights, among which are life, liberty and the pursuit of happiness. I said, "We gave that battlecry to the world while we had slavery." Any government that does not understand that it comes to this meeting with its bag of glories and promises, tragedies and hopes does not understand itself and cannot possibly participate usefully in a discussion about how we can help each other to solve the problems of human rights.

The U.N. president said that no government that ratified the U.N. Charter can ever insist that what it does with its own people is exclusively its own affair. If you cannot talk about human rights in a country, you cannot talk about human beings. That view prevails not just in the Soviet Union, but in the United States on the problems of people in southern Africa and Latin America. Every night in Geneva at 11:00 PM we had an open house for anybody who wanted to come and complain about the human rights problems. Those sessions were quite remarkable considering who came to talk to us: the people, the information, the suffering. Some governments did not like it when we met with people in exile from their country.

Some people think that the Carter Administration retreats on the issue of human rights in eastern European countries. I know that in Belgrade, Ambassador Goldberg not only insisted on discussing specific cases, but he insisted that that topic must be the major agenda item of the reviewing conference.

When I was in Poland, the President of that country had been involved in discussing the human rights problems. The Polish government informed me that it did not want me to speak to the Catholic Intellectual Club. This was not a revolutionary society trying to overthrow the government, this was an authorized Polish group. I told the government that I would speak to everyone on the schedule or no one. We had the meetings in Warsaw. I told the Catholic Intellectual Club that I was there in keeping with President Carter's promise that he would try to respond to the future needs of the Polish people. We had an extraordinary session discussing the complexity of human rights in Poland.

When people say there is a retreat from these concerns, what they are 
doing is accepting the impressions created by what is considered major news. That is a proper part of democracy, but it is not a proper part of objective assessment. There has never been a U.S. ambassador who went to Poland and talked to groups that the Polish government considered objectionable. We have never had an ambassador to Belgrade who insisted on discussing human rights in the eastern countries over the objection of those countries.

The Argentine government protested that we were seeing terrible troublemakers, communists and Che Guevarra's grandmother. I was trying to think how to deal with this protest and this new arsenal of diplomatic weaponry that we had been given. I did not realize the impact it would have, but I knew we had a new weapon when they protested. I used it with the diplomatic skill that I had acquired. I declined a dinner invitation to the Argentine ambassador's residence. I said that I was not coming; that if the choice was talking to the Argentine government or the exiles, I would talk with the exiles. For three or four days it was a confrontation of will. Could the United States refuse dinner at the Argentine ambassador's house? What would happen? They invited me to lunch. We talked about los desaparecidos. I do not know if it decreased the number of people that disappeared in Argentina, but it certainly made clear our concern for real people who suffer in real places.

What we made clear in Geneva-and I think this is central to understanding what this conference is about-is that we do not sit as nationals, but as people. I remember when Zaran, the Russian ambassador in Geneva, got agitated when we discussed the arrests in the Soviet Union . . . that he announced we were ending détente, we were resuming the Cold War. It seemed to me that if we could sit in Geneva and start the Cold War again, the détente was rather fragile. I believed that we could survive the discussion of human rights in the Soviet Union and that détente would survive.

In the course of the argument about whether we could discuss Russian internal affairs, I found that the NAACP had brought a petition to the Human Rights Commission thirty years before claiming that American blacks had been discriminated against and segregated because of their race. The Soviet ambassador was very enthusiastic about investigating racism in the United States. He wanted a commission set up to investigate the Americans right away. I said that at the time the Soviet Union took that position, Mrs. Eleanor Roosevelt was the United States representative and Chairwoman of the Commission. Thirty years ago, Mrs. Roosevelt said that people anywhere in the world that feel their human rights have been violated need to have a place to go and get a hearing. If they come in the right procedure, the Human Rights Commision of the United Nations is the right place to come.

In thirty years since that time we have learned a great deal about our shortcomings. We have moved in the right direction concerning racial relations; we have a long way to go. One reason we have moved is that the world has focused on us. Talking about equal justice under the law, they want to 
know about the Wilmington Ten. Talk about any subject, and people will say, "Wait a minute. Here's what you say, what are you doing?" Thanks to external (and internal) pressure, we have progressed more than we would have otherwise.•

I am trying to convey to this conference what seems to me to be a central fact of the moment. It is a unique moment at which, through a dozen imminent potential catastrophes, we could cease to exit as a planet. We must deal with that. It is a moment when we could waste the fragile and important sense of goodwill toward our country that has begun to develop again, and waste it because we do not understand the opportunity it represents. It is a moment in which the potential for human action across borders, across races, across regions, is higher than it has ever been in most places-southern Africa, the Middle East, Latin America.

I hope that in that sense of opportunity, that sense of potential, people do not relegate everything to government. What can the United States do about Uganda? We are not going back into the business of destabilizing countries or sending in troops when we do not like what they are doing. We have no ambassador there. We have no program of assistance to Uganda. People could do more. Why isn't there an organized boycott of Ugandan coffee by human beings who care about justice and equality? I do not understand the somnolence of the community in general on questions of compassion.

The progress in this community, the changes in our lifetime, for the better in some places, for the worse in others, indicate precisely how much we can influence events at the junctions where events are influenceable. We are at one of those junctions now, this lobotomized state of affairs where half your head knows that the world may end in thirty years and the other half acts like everything is the same because no one sees that they have any responsibility. That has to be dealt with as part of the effort to relate usefully to the world as it is. Central to that is the issue of how to decrease human suffering. If we do not deal with that problem with the breakthroughs that we have, those breakthroughs could turn and destroy us.

I will finish by resurrecting a statement that was uttered almost ten years ago about the things that I have talked about. On the day of the murder of Martin Luther King, Robert Kennedy talked about violence and said this:

There's another kind of violence, slower but just as deadly. Destructive as the shot or the bomb in the night. [T]hat is the violence of institutions-indifference and inaction and slow decay. This is the violence that afflicts the poor and that poisons relations between men because their skin is different colors. This is the slow destruction of a child by hunger in schools without books and homes without heat in the winter, until we learn at last to look at our brothers as aliens, men with whom we share a city but not a community, men bound to us in common dwelling but not in common effort. And then we learn to share only a common fear, only a common desire to retreat from each other, only a common impulse to meet disagreement with force. What we need is not division or hatred or violence or lawlessness but love and wisdom and compassion 
toward one another and a feeling of justice toward those who still suffer, whether they be white or black. My favorite poet was Aeschylus who wrote, "In our heart, pain which we cannot forget falls drop by drop until in our own despair and against our will comes wisdom through the awful grace of God." So let us dedicate ourselves to what the Greeks wrote so many years ago, "Tame the savageness of man and make gentle the life of the world."

That is the essence of human rights. 